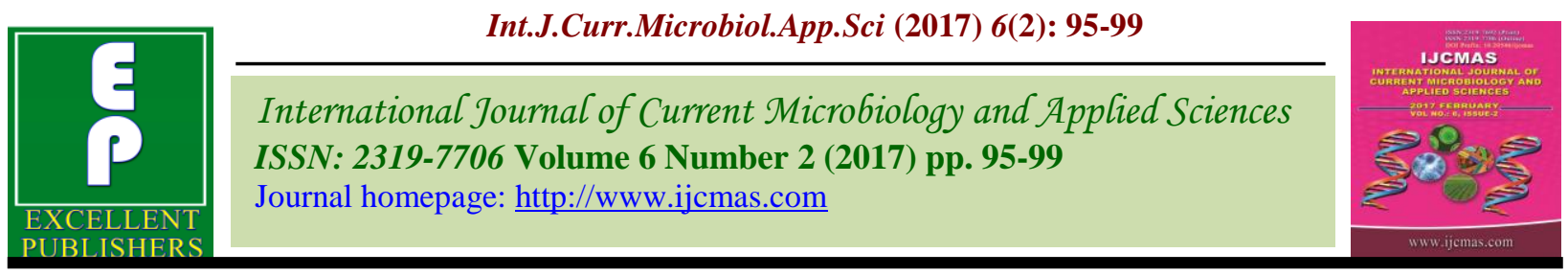

Original Research Article

http://dx.doi.org/10.20546/ijcmas.2017.602.013

\title{
Genesis of the Flora of Specially Guarded Natural Areas - Geygel National Park, Eldarpinery, Garayazy and Korchay State Natural Reservations
}

\author{
V.S. Novruzov, A.A. Bayramova* and Y.A. Aslanova \\ Ganja State University, Ganja Azerbaijan \\ *Corresponding author:
}

\author{
A B S T R A C T
}

\begin{tabular}{|l|}
\hline K e y w o r d s \\
Aftoxton, \\
Alloxton, \\
Genesis, \\
Endem, \\
Relict, Pleosen.
\end{tabular}

Formation of the Caucasian floristic complexes remains as a main problem up today. After the status of the west region of the especially protected natural areas of Azerbaijan have been changed in the state level. For the first time there has been made the inventory of the flora of the Geygel National Park, EldarPinery, Garayazy, Korchay State Natural Reservations. At the result there have been determined 107 families, 467 genera and 1200 species. There have been determined that the Northern Borial, Northern Arctic, the Mediterranean and Front Asian migration waves have great roles on the formation of different life forms in the investigated areas. The flora and floral analyses of the especially protected natural areas in the west of Azerbaijan show that the flora has mainly developed in three ways: By keeping the ancient species, species formation and migration. This does not arouse any doubt that the flora origin is aftoxton and alloxton. According to the poleobotanic information, genetic ties of the flora and areas there has been determined that the Northern Borial, Northern Arctic Mediterranean and Front Asian migration waves have great role on forming of different life forms in the investigated areas.

\section{Introduction}

Abundance of the Aftoxton species is the indicator of the antiquity of the flora. The role of the endemic elements (species, genus, etc) on the historical conception of the flora has great influence too. Existence of any flora depends on the quantity of the endemic elements. Formation of the each flora, including into the area and adaptation process doesn't take place in the same way. Though some species have adapted to the local investigated area condition, but they are under threatening of perishing.

No doubt, this is connected with anthropogenic factors. But remainders of the ancient flora have been kept in the type of relicts in the refigiums. Migrants of the latest period are observed in structure of the flora too, that the same species are in the stage of spreading. But the third group species that we meet in the flora concern to the conservative species (Polojiy, 2001).

In opinion of Krishtofovich (Krishtofovich, 1936) the North Arctic migration wave including the Ukrain and the Siberia entered the Caucasus at the end of the Chalk Age. Grossheym considers that the Arctic III age elements are of the north origin according to the essence of the elements. We think the Arctic III age flora has taken its origin from the Turgay type flora. The Turqay flora has 
completely surrounded the Caucasian areas in the III period. But the Arctic Alpine types could spread widely in the investigation territory in the upper Pliocene Age. In opinions of some investigators as Alpatiyev and Arkhangelsky (1932) there has been formed high mountainous relief in the investigated area.

By the spreading character, bioecological and systematical features the following species are included into the Arctic III period migrants: Juniperus pygmaea, J.sabina, Pinus eldarica, P.kochiana, Orchi spapilionacea, O.punctulata, Allium callidictyon, Galanthus nivalis, Iris grossheimi, I.paradoxa, I.prilipkoana, Juncus my alpigenuas, silt ledebourii, Scillacau casica, Tulipaeicheri, Ophrys apifera, Ferula szowitsiana, Acer trautvetteri, Galium eldaricum, Torularia eldarica, Pyrus eldarica, Scorzonera pulchra, Campanula fominii, Dianthus raddeanus, Rhododendron caucasicum, Cyclamen elegans, Elymus caninus. At present in the GMP in the high upland territories, in the isolated places, in the rocky slopes these species have been kept as the relict of the Ice Age.

Modern spreading and bioecological features of the Mediterranean species observed in the ESDTG and KDTG show that their spreading center is the Mediterranean areas. But some species are met in less quantity in Asia. The Mediterranean species have taken their origin from the III Age. In opinion of Engler there had been a long period of floral exchange between the Mediterranean areas and South Africa, Ethiopia, East Asian Dragon Mountains in the Pliocene age. In the late Pliocene Age the Mediterranean flora did very great migration in different directions and a part of this wave surrounded the KGSS. It has been kept only in the XMOTE. Nodoubt, the Mediterranean migration wave brought much more species in comparing with the present day species. The late orographical system of the Caucasus is connected with building of some water reservations in early XXI and this created available condition for spreading of some Mediterranean heat-loving species. Some species have remained in the refigiums as relicts. So we can meet 25 families, 78 genera and 34 species in the investigation territory and these are the III age and the modern IV age relicts.

Woodsia is a typical Turgay element and it could enter the Caucasian area within the Northern Boreal flora. The geographical analysis of the Eurasian nemoral elements show that the influence of the Paltav flora is felt in them. The great quantity of the nemoral species are met in the middle and southern Europe and also in the broad-leaved forests of Europe. The Turgay species take very small place in this flora. Spreading of the species in the isolated situation within its own areal, shows its being relict. In general the species of this genus have been isolated from the main part of the area. We call them neorealist's.

XMOTE consists of complex geomorphologic systems of some mountain ranges, ravines and bluffs. No doubt, the complex geomorphologic systems do not save the different species in the same way and the migration is not provided in the same way.

Let us pay attention to naturally spreading of some species within XMOTE. For instance, in opinion of professors Grossheym (1936, 1939-1967) and Shagapsayev (2003) the Campanula genus species were formed in the late III age, at the result of the swift species formation process in the Caucasus. As it is known (Kuljzynski, 1923-1924; Novruzov, 2010) the mountain formation process in Europe had ended until the Pliocene Age. In the plain lowlands of KDTG and GDTG the Campanulla genus has not got any relationship. So the same species could be 
formed only on the basis of the high mountain plants. Later, at the result of the morphological and ecological adaptation the Campanula genus species have enlarged their areal. Pliocene Age signs have been kept as relicts in the nival and subnival zones of the GMP.

The Saxifraga genus species are not met in the GMP area and in other reservations and it shows that it is of mountain origin.

The Driyoptris were formed in the GMP and ESDTG within the mesophil forest flora in the late Chalk age. At the beginning of the Ice Age the connection between Europe and Asia was broken off and there were differentiations inside of the areas.

In the late Holocene Age and later on, changing of the climate condition helped spreading of the iris family species in all four reservation areas. No doubt, spreading of the iris family species into the investigation areas took place in the Pliocene Age. It is because the subatlantic climate exceeded in the Caucasus at that age. In the opinions of some investigators (Galushko, 1936) there have taken place the floral reformations for several times.

At present there are met III Age relicts, the Chalk Age stages and comparatively younger IV Age relicts in the investigation area. Investigation of the relicts can be a very valuable scientific base for investigating of the flora of after Ice Age period. Poleobotanical information shortage gives chance to investigate the XMOTE relicts on the basis of floristic, systematical information.

In general the history of flora, the geomorphologic development of the relief is not related with the history of the flowering plants. In opinion of Arkhangelsk (1932) dry climate in the Caucasian territory lasted for a long time in the Mid-Chalk Age. Those arid areas were available for development of some
Cserophit species. Arctoalpic and Antractic species could enter the flora in the Middle of the Chalk Age. In the Caucasus remainders of the flowering plants of the late Chalk Age show that all four XMOTE plants cover were formed in the middle of the Chalk Age. The remainders of the Papulus and Platanus show that the GDTG flora was formed in the middle and late Chalk Age.

The special ecological and fitosenologic features of GMP were a cause for forming of some iris species. Some of them grow in the mid-highland forests. General spreading of the Caucasian irises - irises caucasica, I. Imbricata, I.grossheimii, I.papadoxa, I. demetri has diffusion character and their spreading areal is unequal.

Part of the areal spreads till the Alpine zone in North America and Eastern Siberia. All of these give ground that in the late III Age, at the result of the species formation the iris species could spread in the nemoral zone of holarctica as well as in the GMP (Bayramova, 2013).

Pleistocene Icing Age was a cause for perishing of the ancient tropical and subtropical flora. The III Age relicts have been kept in small amount of refigiums. The ecological plasticity of the species has been kept within its areal in the shelters of the mountain ranges. As a representative of the ancient Turgay flora the species are connected with refigional centers and could be kept as their elementary areal.

Orchis papilionacea L. tropical roots carry Turgay character. The species could enter the investigation area by the turqay way.

Toffee caucasica Stev species in spite of being spread widely, it is observed less in the investigation area. The same species is not related with the refigional centers. As the species entered the investigation area in the 
Neogene Age (IVAge) it could not spread in the area widely. Because there took place the exchange of species among them. Entering of the species the investigation area could be by the mountain ranges of the Carpathian, Crimea and Caucasus (Red Book of the Azerbaijan Republic II edition, 2013; Esgerov, 2005).

The Lily family (Liliaceae) was known in the Paleogene Age 58 million years ago and was registered as a family by Antoine Laurent de Jussieu in 1789. In the same time Arthur Cronguist or Robert gave perfect information about 250 genera and 3500 species. In the 1980s while classifying the flowering plants, the lily was more observed. At the end of the decade the founder of the Botany and Natural Sciences Gardens, Kew and Edinburgh organized commission to investigate the homogeny Lilia genus and to supply the British museum with the herbariums. The commission gave the phylogenetic analysis of the family, analysis of 24 new genera, DNT and morphological information (especially reproductive morphology) altogether. During the late 20 years the old lily family was substituted with new Liliaceae family. On the ground of this classical analysis the Liliaceae family was supported by some scientists. Classical definition of the Liliaceae family has shown that it doesn't reflect the real phylogenetic connections between the artificial components. The botanists note that it is easy to distinguish the Liliaceae family genera and species in comparison with other families. The species of the family have spread from the upper highland zones to the lower highland zones of Azerbaijan. 25 genera and 150 species have been included to the family. A number of lily species have widely spread in the forests, plains, upper highlands and even in the deserts (Bayramova, 2013).

Some orchids develop underground, some (lithophytes) on the rocks, in the earth and some develop on the other plants and trees and have epiphyte life style. The orchids have adapted to the ecological environment (except arid areas) and have widely spread tropical zones. For instance, there are 120 species in the past USSR territory, 50 species in Azerbaijan, 60 species in Far East, 200 species in Vietnam, 100 species in Florida, 307 species in Cuba and 1055 species in Venezuela. At the result of the intensive anthropogenic influences the number of the orchid family species decreases sharply. Majority of the orchid family species have been included into the "Red Book" and it is forbidden to gather them.

To determine the history, formation and later development of the flora, the relict species together with endems are of great importance. Relict species are the remainders of the past geological ages in structure of the modern flora. 75 years ago Qrossheyim (1936) wrote that one of the most important issues for the future investigators would be studying all the relict species and systematizing all of the relicts exactly. In order to determine the types of the relicts in the XMOTE they have been divided into the following types being based on Grossheym and Shagopsayev (2003).

\section{1) III Age relicts}

2) Ice Age relicts (plestosen)

3) After Ice Age relicts (kserotermin)

Twenty five families, 32 genus, 78 species are included into the III Age relicts. Brassica has been represented by 7 species, Saxifraqa by 4 species, Poacea, Fabaceae, Rosaceae by 3 species and Caryorhyllaceae, Papaveraceae by 2 species. 11 families have been represented by one species.

In the scientific literature we can meet the information about spreading of the III Age relicts in the Caucasus and rep [resenting as edificators in the favorable edificators (Shkhagapsoyev, 2003). 
The GMP species as Rhododendron Caucasia, Betulapendula, Nepetaspina, Drabalon gisiligua have spread in the height of 1800-2300 m. higher sea level and they are included into the progressive relicts. In opinion of Y.A. Bush the species of Campanulla (C.minsteriana, C.hohenackeri, C.schelkownikowii, C.latifolia, C.rapun-culoides, C.bononiensis, C.trautvetteri, C.alliariifolia) Papaver (P.orientale, P.montanthum, P.fugax, P.persicum, P.hybrida, P.macrostomum) Potentella (P.micrantha, P.lomakinii, P.argentea, P.canescens, P.obscura, P.argaea) Ranunculus (R.repens, R.caucasicus, R.trisectilis, R.baidarae, R.brachylobus, R.crassifolius, R.oreophilus, R.meyerianus, Saxifraqa (S.cymbalaria, S.sibirica, S.moschata, S.pontica, S.exarata, S.adenophora) could exist in the areas that were free of ice during the Ice Age. But when the glaciers withdrew some factors prevented their expanding of the real.

\section{References}

Arkhangelskiy, A.D. 1932. "Geological Development and Geological History of the USSR”. IV edition., M-L., p 263.

Bayramova, A.A. 2013. "LiliaceaeJuss of the Specially Guarded Natural Areas of the West Region of Azerbaijan" Azerbaijan Agrarian Scientific J., № 2, p.94-97.

Bayramova, A.A. 2013. "Floral Biodiversity of the Specially Guarded Natural Areas of the West Region of Azerbaijan”. (Monography), Bak1, Elm, 2013.p 327.

Bayramova, A.A. 2013. "Orchidaceae of the Specially Guarded Natural Areas of the West Region of Azerbaijan". News of ANSA (Biol. Med. Sci.,), volume 68. №3.pp 204-210.

Engler, $\quad$ A. $\quad 1879 . \quad$ Versucheiner
Entwicklungsgeschichte der Pflanzenwelt.

Esgerov, A.M. 2006. "Higher Plants of Azerbaijan" Conspects of the Flora of Azerbaijan" volume1, Baku, "Elm", 2005. Volume2, Baku "Elm", volume 3, Baku, Elm.

Galushko, A.I. 1974. "Main refigiums and relicts of the highland flora of the west part of the Central Caucasia" Selected Volume "Problems of Botany. Flora of the highlands" Nauka, 6, p 19-26.

Grossheym, A.A. 1936. "Analysis of the Caucasus” Baku, p 269.

Grossheym, A.A. 1939-1967. "Caucasian Flora" 2 edition., volume1, Baku 1939 p404.Volume 2. Baku 1940. p284. Volume 3. Baku 1944. p322. Volume 4.M-L., 1950. p314. Volume 5.M-L., 1952. p456. Volume 6.M-L., 1962. P424, Volume 7. M-L., 1967. p894.

Krishtofovich, A.N. 1936. "Development of the Botanical-Geographical Provinces of the North Hemisphere since the Late Chalk Age". Sov. Bot., 3 edition.p 9-14.

Kuljzynski, S. 1923-1024. "Dasboreale und arktisch alpine element in der mitteleuropaischen flora". Bull. Intern.Acad.Polon. Sci.Lettr. Cl.Sci. Math.natur., ser. Biol. Sci. Natur., p.127-214.

Novruzov, V.S. 2010. "Basis of the Fitocenology (Geobotany)" Baku, Elm, P. 306.

Polibin, I.V. 1930. "Later Chalk age Flora of South-Eastern Transcaucasia" Organization of the Geological Development" Volume 49.№7.p 781-795.

Polojiy, A.V. 2001. "Understanding of the Desert Flora Geneses in the West Pirenerian Siberia” Krilovla volume 3. № 2, Pp58-62.

Red Book of the Azerbaijan Republic II edition. Baku, 2013. p 673.

Shkhagapsoyev, S.Kh. 2003. Analysis of the Floral Complex of Western Part of the Central Caucasus. Nalchik, Pp 217.

\section{How to cite this article:}

V.S. Novruzov, A.A. Bayramova and Aslanova, Y.A. 2017. Genesis of the Flora of Specially Guarded Natural Areas - Geygel National Park, Eldarpinery, Garayazy and Korchay State Natural Reservations. Int.J.Curr.Microbiol.App.Sci. 6(2): 95-99.

doi: http://dx.doi.org/10.20546/ijcmas.2017.602.013 